\title{
Retraction: An Investigation into the Iranian EFL Language Learners' Attitudes on TOEFL iBT
}

\author{
Kamal Heidari Soureshjani*, Parisa Riahipour and Arezoo Safikhani
}

* Correspondence:

k86tefl@yahoo.com

Islamic Azad University, Shahrekord

Branch, Iran

\section{Retraction}

This article is retracted.

Hereby, I, Kamal Heidari Soureshjani, the lead author of the article titled "An Investigation into the Iranian EFL Language Learners' Attitudes on TOEFL iBT" (Soureshjani et al. 2012) published in Language Testing in Asia, Volume 2 Issue 3 in July 2012, officially ask you to retract the article. The reason for such a decision is that I recently noticed from a colleague that the real number of participants is less than what has been mentioned in the article. Therefore, I immediately decided to let the journal officials know. I express my deepest apologies to the journal officials and also all readers for such an unintentional incident.

Published: 3 December 2013

\section{References}

Soureshjani, K., Riahipour, P., \& Safikhani, A. (2012). An Investigation into the Iranian EFL Language Learners' Attitudes on TOEFL iBT. Language Testing in Asia, 2, 18-32.

doi:10.1186/2229-0443-3-17

Cite this article as: Soureshjani et al:: Retraction: An Investigation into the Iranian EFL Language Learners' Attitudes on TOEFL iBT. Language Testing in Asia 3:17.

\section{Submit your manuscript to a SpringerOpen ${ }^{\circ}$} journal and benefit from:

- Convenient online submission

Rigorous peer review

- Immediate publication on acceptance

- Open access: articles freely available online

- High visibility within the field

- Retaining the copyright to your article

Submit your next manuscript at $>$ springeropen.com 